\title{
FIRE REGIME IN THE PIMENTEL BARBOSA INDIGENOUS LAND, MATO GROSSO, BRAZIL
}

https://doi.org/10.4215/rm2020.e19018

\author{
Lívia Lima Leite Aguiar $\mathrm{a}^{*}$ - Patrick Thomaz de Aquino Martins ${ }^{b}$
}

(a) Master in Natural Resources of the Cerrado. Goiás State University, Anápolis (GO), Brazil.

ORCID: https://orcid.org/0000-0002-0736-569X. LATTES: http://lattes.cnpq.br/2207833391337937.

(b) $\mathrm{PhD}$ in Geosciences and Environment. Professor at Goiás State University, Formosa (GO), Brazil.

ORCID: http://orcid.org/0000-0003-3814-3982. LATTES: http://lattes.cnpq.br/8863685587967952.

\author{
Article history: \\ Received 23 March, 2020 \\ Accepted 02 June, 2020 \\ Publisher 15 August, 2020
}

\section{(*) CORRESPONDING AUTHOR}

Address: Rua 242, n. 53, Reserva Jaraguá, Vila Montecelli, 74655-370, Goiânia, Goiás, Brasil.

E-mail: livia.limaleite@gmail.com

\section{Abstract}

The Pimentel Barbosa Indigenous Land (PBIL), which belongs to the Xavante ethnic group, is in the region with the highest annual fire activity in the world, indicating the need for accurate monitoring of spatial and temporal patterns of fire events. In this context, this study characterizes the fire regime in the PBIL from 1984 to 2018 and correlates to the types of vegetation and land use, and the culture of the local Xavante people. Fire scars were identified, mapped and then their spatial distribution and frequency were analyzed, including aspects of plant typology and land use. Over the 34 -year study period, the burned area in the PBIL was $1,500 \%$ larger than its total area, with evidence of burning in over half the area in several years. There was no spatial pattern to indicate the use of traditional practices. The Savanna areas and agricultural land accounted for more than $90 \%$ of the total affected area. The fire frequency was classified as medium or high (9 to 34 occurrences) for all land use types, showing that twenty times the most common frequency. The Xavante went through forced migrations, and the expropriation and fragmentation of their territory have altered their semi-nomadic way of life. This has resulted in sedentarization, the modification of their territorial structure, and the integration of their culture into mainstream Brazilian social norms. This process is mainly responsible for the current burning scenario, indicating the need for actions so that fire can be used as a sustainable tool.

Keywords: Fire; Mapping; Xavante; Frequency.

\section{Resumo / Resumen}

\section{REGIME DE QUEIMA NA TERRA INDÍGENA PIMENTEL BARBOSA, MT, BRASIL}

A Terra Indígena (TI) Pimentel Barbosa, da etnia Xavante, está localizada na região de maior atividade anual de queima do mundo, denotando a necessidade de um monitoramento oportuno e preciso dos padrões espaço-temporais de ocorrência do fogo. Neste sentido, o presente trabalho objetivou caracterizar as ocorrências de queima na referida TI, entre os anos de 1984 a 2018, relacionando-as tanto com as diferentes tipologias vegetais e uso do solo presentes na TI quanto com o modo de vida Xavante. Cicatrizes de queima foram identificadas, mapeadas e analisadas quanto a sua distribuição espacial e frequência, incluindo o aspecto da tipologia vegetal e uso do solo. Em 34 anos, a TI queimou uma área superior a $1.500 \%$, com o registro de queima de mais da metade da área em diversos anos, não apresentando padrão espacial que expresse as práticas tradicionalmente utilizadas. As tipologias vegetais savânicas e o uso agropecuário apresentaram mais de $90 \%$ da área atingida. Em todas as tipologias e uso, predominou frequência classificada como média ou alta, de 9 a 34 ocorrências, sendo 20 vezes a frequência mais comum. Os Xavantes passaram por migrações forçadas e pela expropriação e retalhamento do seu território, culminando em alterações no padrão seminômade, na sedentarização, na modificação da estrutura territorial e na integração ao padrão da cultura brasileira. Este processo é indicado como responsável elementar ao estabelecimento do cenário de queima identificado, se fazendo necessárias ações para que as queimadas possam ser utilizadas como uma ferramenta sustentável.

Palavras-chave: Fogo; Mapeamento; Xavante; Frequência.

RÉGIMEN DE QUEMAS EN TIERRA INDÍGENA PIMENTEL BARBOSA, MATO GROSSO, BRASIL

La Tierra Indígena (TI) Pimentel Barbosa, de la etnia Xavante, se encuentra en la región con la mayor actividad anual de quema en el mundo, lo que denota la necesidad de un monitoreo oportuno y preciso de los patrones espacio-tiempo de ocurrencia de incendios. En este sentido, el presente estudio pretendía caracterizar las ocurrencias de quema en esa TI, entre los años 1984 y 2018, relacionándolas con los diferentes tipos de vegetación y uso del suelo presentes en ella. Las cicatrices de quemas fueron identificadas, mapeadas y analizadas para su distribución espacial y recurrencia, incluyendo el aspecto de la tipología de las plantas y el uso del suelo. En 34 años, la TI se quemó em mas de $1500 \%$ de su área, los registros de quemas em mas de la mitad de la zona durante varios años, no muestra ningún patrón espacial que muestre las practicas tradicionalmente utilizadas. Los tipos de vegetación de sabana y el uso agrícola representaron más del $90 \%$ de la superficie afectada. En todos los tipos y uso, predominó la recurrencia clasificada como media o alta, de 9 a 34 recurrencias, siendo 20 veces la frecuencia más común. Los Xavantes pasaron por migraciones forzadas y la expropiación y destrucción de su territorio, culminando en cambios en el patrón seminomade, sedentarización, modificación en la estructura territorial e integración con el patrón cultural brasileño. Este proceso se indica como el principal responsable del establecimiento del escenario de quemas identificado, haciendo necesarias algunas acciones para que las quemas pueden utilizarse como una herramienta sostenible.

Palabras-clave: Fuego; Mapeo; Xavante; Frecuencia. 


\section{INTRODUCTION}

The genesis of fire is related to the origin of plants and it contributes to biogeographical landscape changes that impact significantly on how ecosystems function, playing a key role in the evolution of fauna and flora, which have undergone adaptations in response to the action of fire (PAUSAS; KEELEY, 2009).

Fire's connection to the evolution and ecology of terrestrial lifeforms includes the human species (BOWMAN; MURPHY, 2010). Humans' habitual use of fire began in the Lower Paleolithic period (KARKANAS et al., 2007), and the ability to control fire extended its use beyond ecological limits, providing humans with a powerful tool for warming, cooking, protection, deforestation, and soil fertilization (CHUVIECO, 2009).

Although humans adapted fire for their use, it is often more destructive than intended, consequently, a better understanding of humans' relationship with fire is required together with an optimum balance between land management needs and the sustainability of natural ecosystems (PAUSAS; KEELEY, 2009).

The combined effects of anthropogenic activities, climate, and vegetation form a clear geographic pattern of fire activities on a planetary scale; most of these activities are concentrated in tropical savanna regions (BOWMAN; MURPHY, 2010). In Brazil, these regions are represented by the Cerrado biome, which is composed of forests and grasslands and has the largest area and greatest biodiversity of flora and fauna in the world, covering approximately $25 \%$ of the Brazilian territory (EITEN, 1972; COUTINHO, 1990).

In general, morphological and physiological characteristics and adaptations protect Cerrado vegetation from fires. Morphologically, some species have thick bark, and the gemmae and underground organs that storage energy (xylopodium) are protected. The physiology of some species moves nutrients to underground tissues at the beginning of the dry season, induces regrowth, and interrupts dormancy (COUTINHO, 1990). However, these adaptations are related to a natural fire regime, when fires occur during the rainy season and the transition months between the dry and rainy seasons (SATO et al., 2010).

In contrast, anthropogenic fires in the Cerrado are started in the dry season and cover large areas, unlike natural fires that burn small areas and are rapidly ended by rainfall (PIVELLO, 2011; FRANÇA, 2010). These fires sometimes get out of control and consume large forest areas (MIRANDA et al., 2010; RAMOS NETO; PIVELLO, 2000). This alteration in the natural fire frequency affects different characteristics of the vegetation, causing changes in woody vegetation (SATO et al., 1998) and nutrient cycling (MIRANDA et al., 2002; MIRANDA et al., 2010). Carbon, nitrogen, and sulfur losses also occur (NARDOTO et al., 2006).

Anthropogenic fires in the Cerrado are related to the cultures of the Indigenous populations who live in this biome. Indigenous people use fire to manage natural resources, fertilize the soil, and open up areas for cultivation (POSEY, 1987). One of the ethnic groups whose culture includes the use of fire is the Xavante, they use fire extensively to clear areas for crops and capture a high number of animals in a short time (LEEUWENBERG, 1997; MELO, 2013; WELCH et al., 2013; MISTRY; BIZERRIL, 2011).

The Pimentel Barbosa Indigenous Land (PBIL) is one of the Xavante reserves, located in the south of the Brazilian Deforestation Arc, it is the region that has the highest annual fire activity in the world (GIGLIO et al., 2006). The Arc results from the expansion of agricultural frontiers into peripherical regions of the Amazon biome (southeast of the state of Pará and part of the states of Mato Grosso, Rondônia, and Acre), where the predominant land uses are livestock and soybean crops (FEARNSIDE, 1999).

Due to the magnitude and importance of the impact of fires on tropical savanna regions (PEREIRA, 2003), precise monitoring of spatial and temporal patterns of fire events is necessary. In Indigenous lands, these studies are just beginning, especially when the availability and popularization of data collection tools are taken into account. Thus, more studies are required to better understand the presence of fire in these areas. In this context, this study aims to characterize the fire regime in the PBIL, based on data from 1984 to 2018, and to correlate it to the different plant typologies and land uses in the area and to the culture of the Xavante Indigenous people who inhabit the PBIL. 


\section{MATERIAL AND METHODS}

\section{STUDY AREA}

The Pimentel Barbosa Indigenous Land (PBIL) has a population of 1,743 Indigenous people (IBGE, 2010) distributed over 13 villages (Figure 1). It was legally recognized on August 20, 1986, by decree $n^{\circ} .93,147$ (ISA, 2019) and is located by the Rio das Mortes River, within the Xingu River Basin, in the municipalities of Canarana and Ribeirão Cascalheira, state of Mato Grosso, Brazil. The reserve has an area of 328,966 hectares (FUNAI, 2019).

The region's climate is classified as central semidry tropical, with mean temperatures between $18^{\circ}$ and $24^{\circ} \mathrm{C}$ in the coldest month, and a mean annual rainfall between 1,200 and $1,700 \mathrm{~mm}$; the rainiest months are November, December, and January (NOVAIS, 2019).

Cerrado vegetation predominates and there is a heterogeneous gradient in height and density. At one extreme of the area, there are forest formations, including the Cerrado-Amazon transition forests in the northwest of the PBIL, these are succeeded by savanna formations and then grasslands at the other end of the zone (EITEN, 1972).

Approximately one-third of the PBIL is composed of plains that are partially submerged during the seasonal floods of the River das Mortes (PRADA; MARINHO-FILHO, 2004). The five physiognomies found in the PBIL are savanna plains with riparian forest, also known as gramineous savanna, composed mainly of grass species, small shrubs, and palm trees; savanna plains without riparian forest; arboreous savanna with riparian forest; arboreous savanna without riparian forest; dense savanna; and transition forest (IBGE, 2012). 


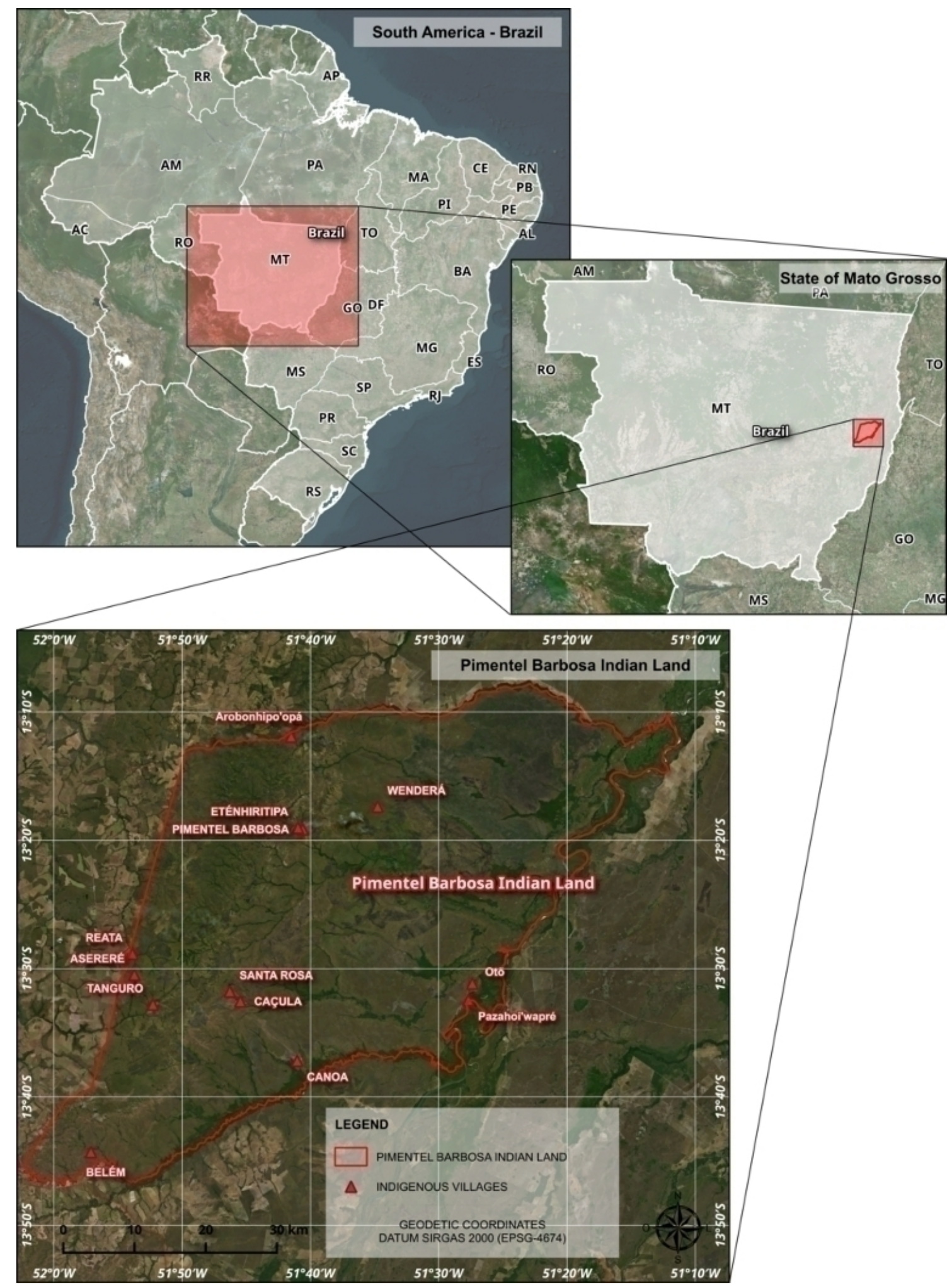

Figure 1 - Map of the Pimentel Barbosa Indigenous Land.

The region's relief is marked by two formations. In the west of the PBIL is the Serra do Roncador, positioned from North to South it is predominantly hilly and is interspersed by plateaus and steep scarps with altitudes of 300 to $400 \mathrm{~m}$ at the highest points.

The Araguaia or Bananal depression is in the east of the IL, it follows the banks of the River das Mortes and is composed of a sediment flood plain, also known as Pantanal do Araguaia (WELCH et al., 2013). 


\section{OUTLINE AND FREQUENCY OF FIRE SCARS}

The areas with fire scars were mapped using the QGIS program, based on orbital Landsat images (NASA-USGS) available in the Earth Explorer online portal (https://earthexplorer.usgs.gov).

The fire scars appear on the satellite images as dark patches caused by the layer of charcoal and ash deposited on the soil after the vegetation is burnt, exposed soil, and post-burning vegetation regrowth, which contrasts with the surrounding vegetation and absorbs electromagnetic radiation on different bands of the optical spectrum, including the near and medium visible infrared range ( 0.4 to 2.5 $\mu \mathrm{m})$ (FRANÇA et al., 2007).

The period from 1984 to 2018 was used, when the Landsat program provided free orbital images with compatible quality and resolutions (WILLIAMS et al., 2006). However, there was an interruption in image availability in 2012 because of problems in the Landsat 7 image acquisition, which was the only active program that year, resulting in images with empty spaces and noise (PIRES; FERREIRA JÚNIOR, 2015).

As the study region has less rainfall and thus low cloud coverage between May and October (SANO et al., 2007) the data from this period was used for the analysis. Another reason for using information from these months is that between May and September, the biomass is more flammable and susceptible to the rapid spread of fire in large areas of natural vegetation (ARAÚJO et al., 2012) Also, burning is unusual between October and March (COUTINHO, 1990).

The fire scars were identified through 153 satellite images from Landsat 5, 7, and 8 observations, using TM, ETM+, and OLI sensors, respectively, at the orbit-point 224-069. The images were processed and available in the Collection 1 Level 2 inventory. This total corresponds to all the available images for the study period, except those that had no fire scars or where they were redundant, and those with excess clouds, flaws, or noises.

The images' reference coordinates were standardized, adopting the SIRGAS 2000 system (UTM zone 22S). Composite color images were generated within bands 5 (medium infrared), 4 (near-infrared), and 3 (red), in the respective red, green, and blue channels (R5G4B3), using Landsat 5/TM and 7/ETM+ and the equivalent R6G5B4 in the of the Landsat 8/OLI scenes, as used in other studies that followed the same methodology (FRANÇA et al., 2007; PAULINO; MARTINS, 2016; ALVARADO et al., 2018).

The composite images were cropped based on the georeferenced limit of the PBIL available in the FUNAI database (Brazilian Indian Foundation; http://mapas.mma.gov.br/i3geo/datadownload.htm).

The fire scars were identified exclusively by a visual interpretation of the Landsat images, using the Gimp Selection Feature plug-in (https://github.with/lmotta/catalog-on-the-fly) for assisted vectorization, which uses segmentation algorithms of features. The fire scar polygons were outlined and converted into vector images (shapefile). This plug-in integrates QGIS and GIMP (GNU Image Manipulation Program) software, enabling the use of functionalities implemented in the GIMP on images whose spatial reference is maintained by the plug-in.

The Fuzzy Select tool (Magic Wand), implemented in the GIMP, was used to outline the burned areas. This tool selects areas from an image by color similarity (https://docs.gimp.org/en/gimp-tool-fuzzy-select.html). This tool was used due to its ease of use and the possibility of adjusting the limits of area and color similarity to the outline of the segment at any time, resulting in a refined and appropriate detection of the various environmental conditions and fire scars in the study area.

The choice of tools also considered the vectorization speed when compared to manual procedures, given the large number of images to be analyzed, and the possibility of visual validation during the vectorization, so that the limit values can be adjusted to a better outline of the fire scar when required.

The resulting outlined vectors from the burned areas of each image were unified, forming a layer for each year. These areas were calculated, and the value 1 was attributed to each polygon. The vector layers for each year were rasterized and converted into binary images, in which values 1 are burned areas and values 0 are areas with no data.

The binary images were piled and then generated an image of the frequency of fires in the study area, using Boolean sum techniques. 


\section{FIRE OCCURRENCES ACCORDING TO PLANT TYPOLOGIES AND SOIL USE}

The layers of fire scars and fire frequency were overlapped on the plant typology and land use maps (Figure 2), using the QGIS geospatial intersection algorithm (overlay). The plant typology and land use map was provided by FUNAI, which had previously prepared it for the Socioenvironmental Impact Study of the Uruaçu-Vilhena Railroad (EF 354; CTI Indigenist Work Center) and identified seven classes based on the classification of the Brazilian Institute of Geography and Statistics (IBGE, 2012). Five plant typologies were found in the PBIL: agriculture, water bodies, arboreous savanna with riparian forest, arboreous savanna without riparian forest, dense savanna, park savanna with riparian forest, and Cerrado-Amazon transition forest.



Figure 2 - Plant typologies and soil use map of the Pimentel Barbosa Indigenous Land.

The map made by FUNAI (Portable Document Format, PDF) was georeferenced using the same coordinate reference system used for the other geospatial data (SIRGAS 2000 / UTM zone 22S) and was manually vectorized in the QGIS.

The results of the overlay were used to organize the data; each plant typology and soil use class was divided into three classes, considering the mean interval between the fire frequency in the study period, according to the area occupied in the PBIL. The classes established were: no occurrence, low frequency ( 1 to 8 incidences of burning), medium frequency ( 9 to 16), and high frequency (17 to 34 ).

\section{RESULTS AND DISCUSSION}

\section{ANNUAL FIRE EVENTS}

The 34-year study period had an intense fire regime, with fires recorded each year, affecting an area of approximately 5,047,664 ha $(1,534.39 \%)$, considering the sum of extensions calculated for each 
year. This represents more than 15 times the total area of the PBIL. The annual number of fires and percentages are shown in Figure 3.

Large fires, covering above $50 \%$ of the total PBIL area, occurred in fourteen of the years in question. In addition, there was a high variability in the extension of the annual fires. The highest incidence was in $2001(39,463.6$ ha $(72.79 \%)$, followed by $1998(236,155.38$ ha, $71.79 \%), 2016$ (214,447.28 ha, 65.19\%), 2007 (211,771.7265 ha, 64.37\%), $2005(205,955.19$ ha, 62.61\%), 2003 $(201,646.59$ ha, $61.30 \%)$, and $1994(199,371.58$ ha, 60.61\%). The lowest number of burned areas were identified in 1985 (45,262.42 ha, 13.76\%), 1990 (65,442.49 ha, 19.89\%), and 1992 (49,963.98 ha, $15.19 \%$ ) (Figure 3).

For the first twenty-nine years of the analysis, the fires in the PBIL were cyclical (Figure 3), however, in the last five years an intense fire event was followed by a smaller one. Although this appears to be the result of management, similar patterns have also been found in other studies of fire events in the Cerrado (PEREIRA JÚNIOR; GAMA, 2010; DALDEGAN et al., 2014), associated with the recovery of the vegetation and critical biomass accumulations, which provide conditions for conflagrations (FRANÇA et al., 2007).

Historically, the Xavante drew on their traditional knowledge to use fire for collective hunting activities whilst maintaining the integrity of local resources. Their expertise took into account factors such as the time of the year, vegetation type, soil moisture, leaf dryness, climate, time for recovery of each plant typology, natural barriers, fire propagation speed, local fauna species, the location of private properties, and a ritual calendar (LEEUWENBERG; ROBINSON, 2000; MELO, 2013; MELO; SAITO 2011; WELCH et al., 2013). However, Leeuwenberg (1994) found a decline the Xavante's traditional hunting practices and reported an irrational and repetitive use of fire by the current generation.

Traditionally, the way the Xavante hunt using fire is not solely a form of management, instead, it is a strong symbol of ethnic identity that is invaluable for their cultural integrity (WELCH et al., 2013). This type of hunting creates a circle over large areas where controlled fires are set. Often the flames are put out to avoid fires spreading beyond the circle. As a result, animals are trapped by the fire and the smoke makes them easy prey for the hunters. The "fire patios or corridors" are located where animals gather or cross so that many animals are caught in a specific area (LEWIS; FERGUSON, 1988).

The attempt to identify a spatial representation of this practice indicates that it is diminishing, as it was not possible to determine spatial patterns of fires for the study period (Figures 4, 5, and 6) that indicate those started by the Xavante. Changes in the semi-nomadic pattern, the sedentarization in the Indigenous lands, and the integration of their culture with Brazilian norms are possible factors that have caused traditional models of fire use to be abandoned (FRAGOSO et al., 2000). 


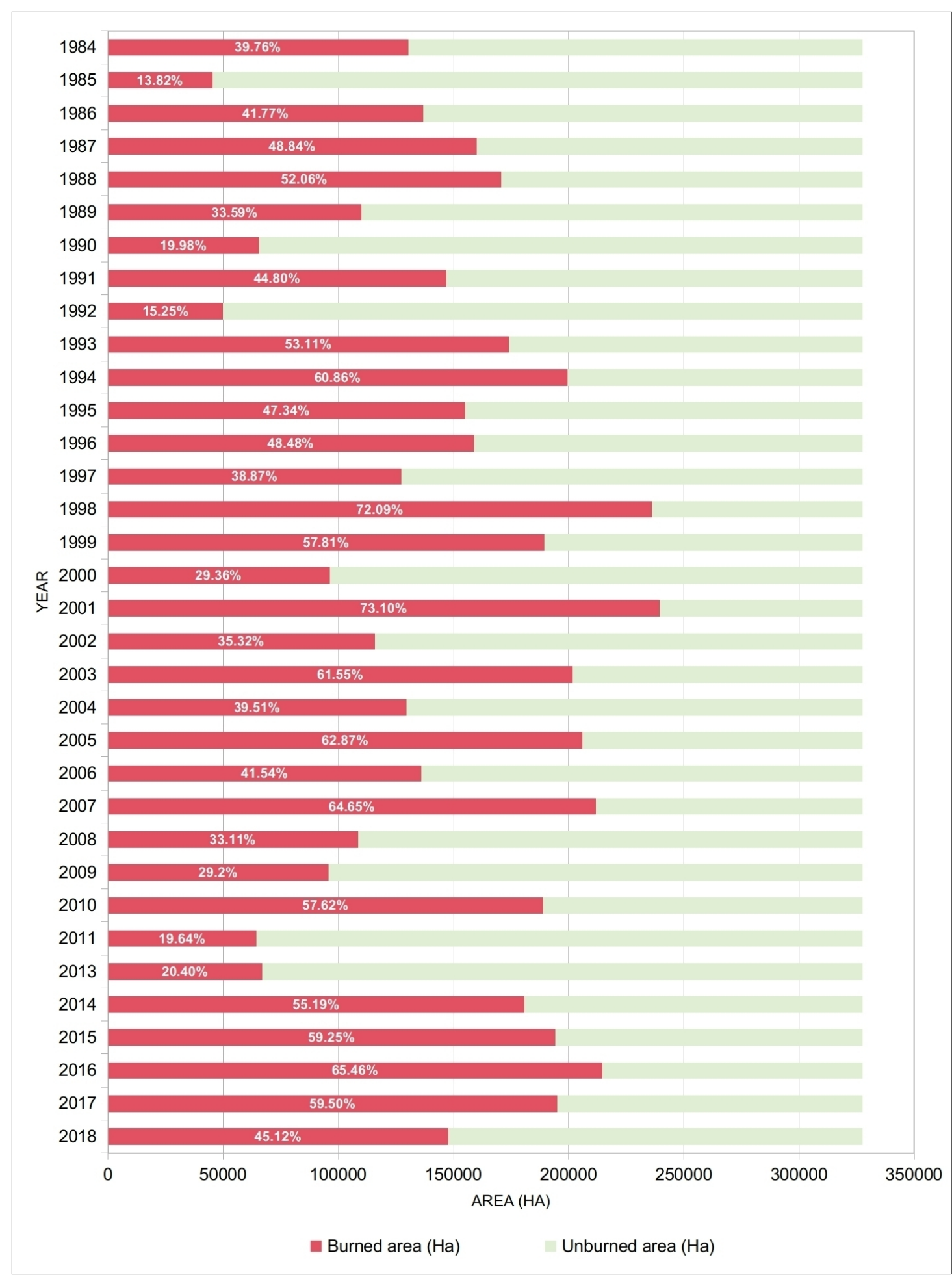

Figure 3 -The burned areas in the Pimentel Barbosa Indigenous Land from 1984 to 2018 (except 2012). 

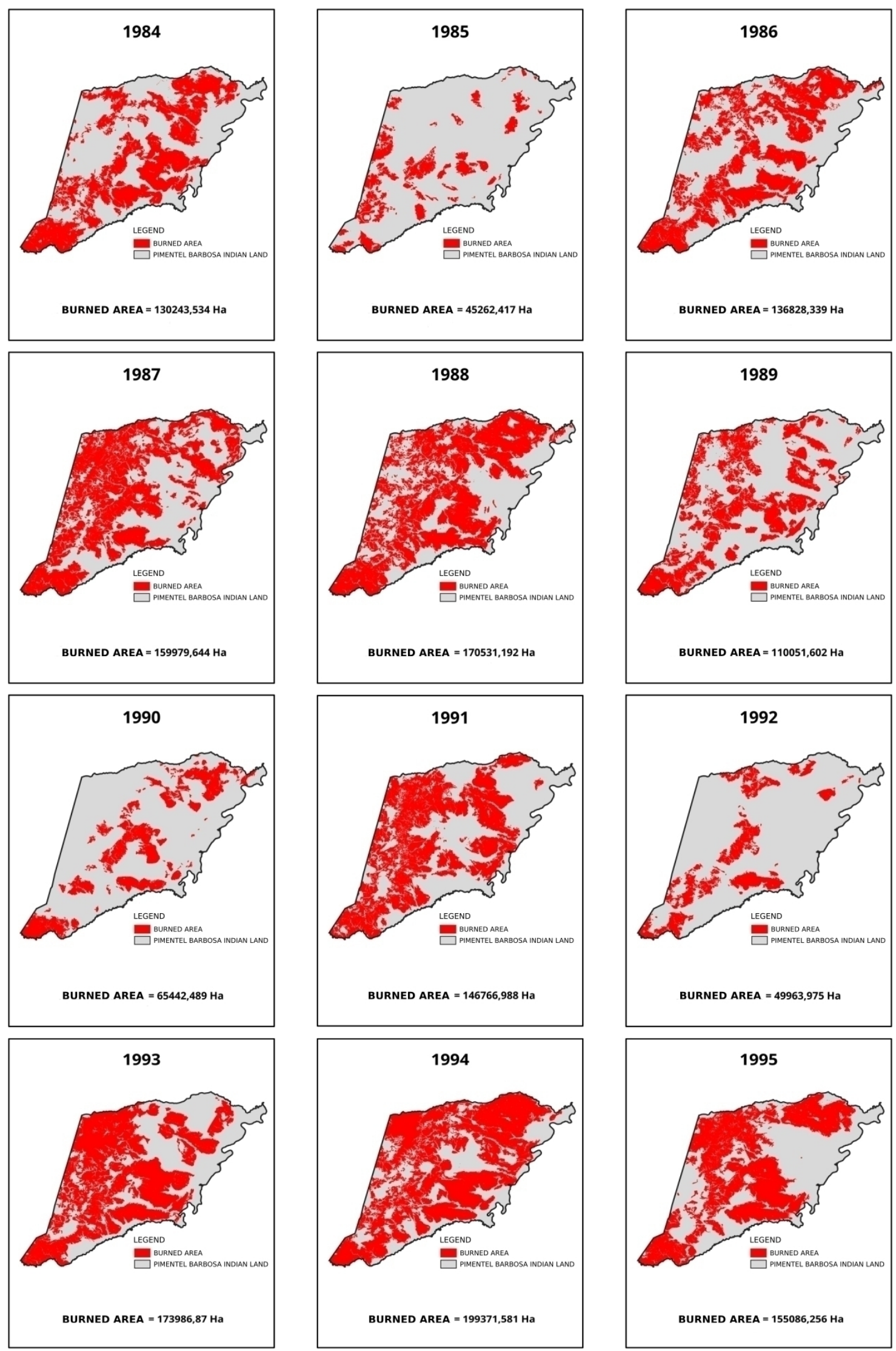

Figure 4 - Annual distribution of fire events (1984-1995). 

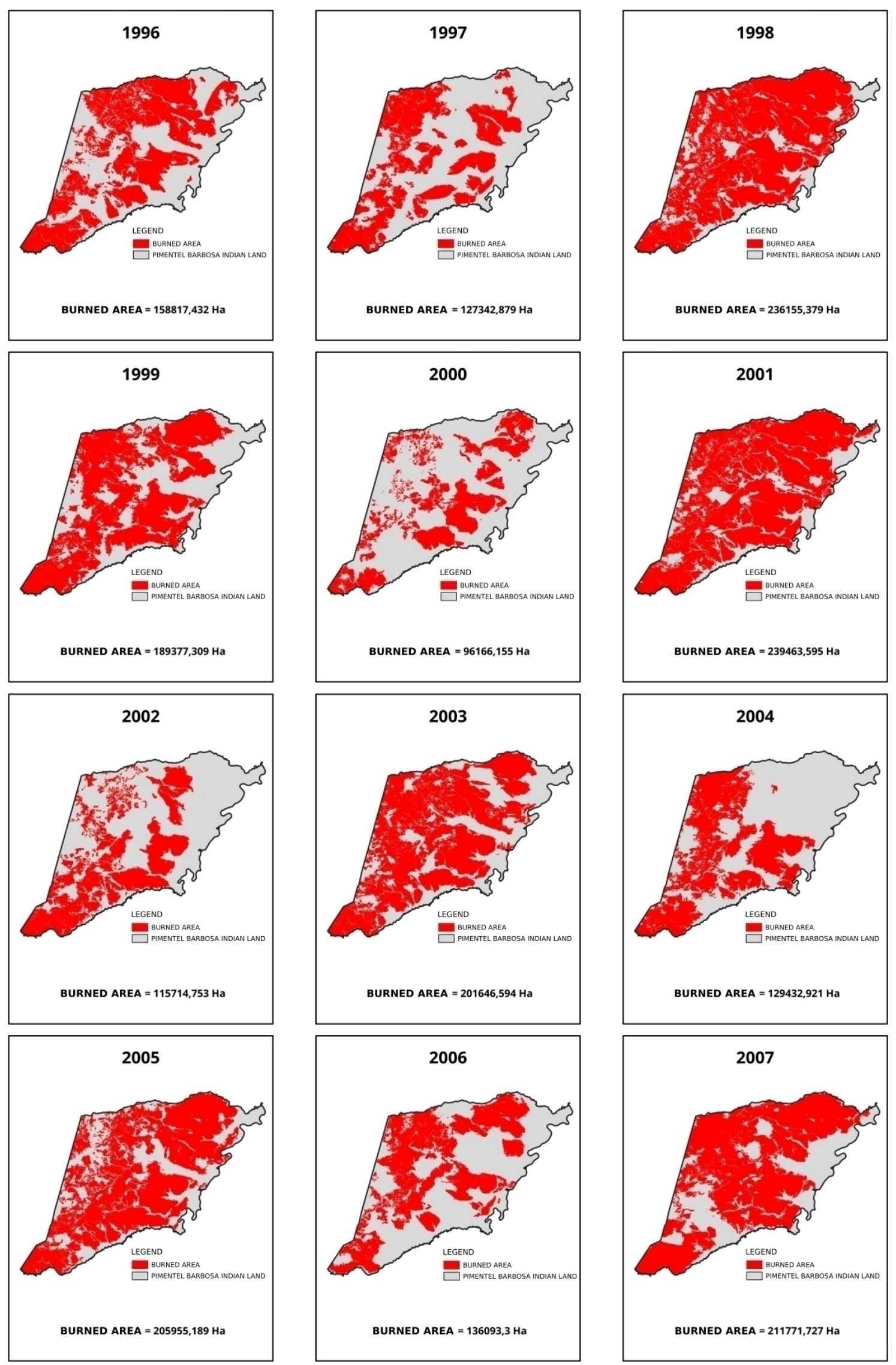

Figure 5 - Annual distribution of fire events(1996 - 2007). 

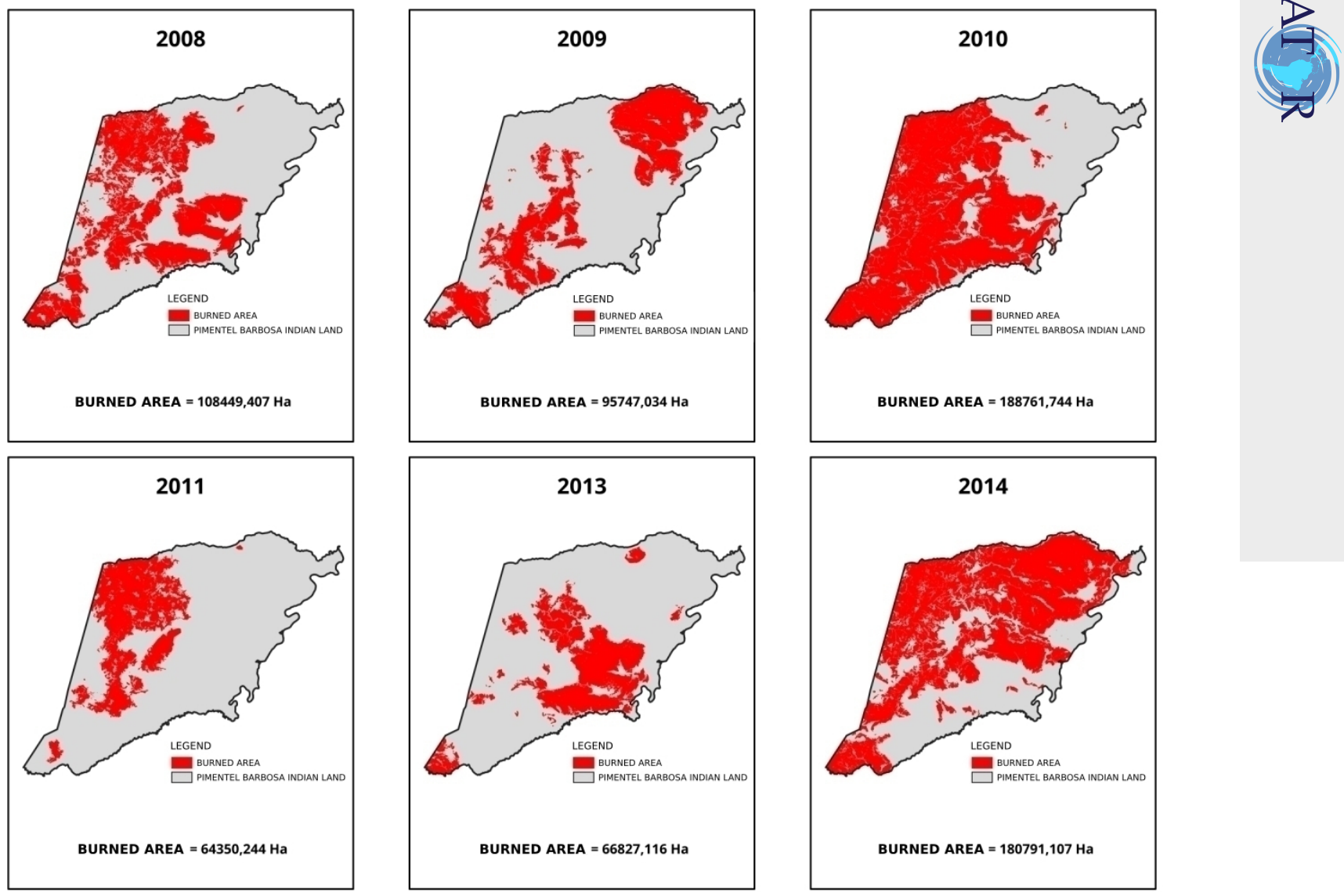

BURNED AREA $=188761,744 \mathrm{Ha}$
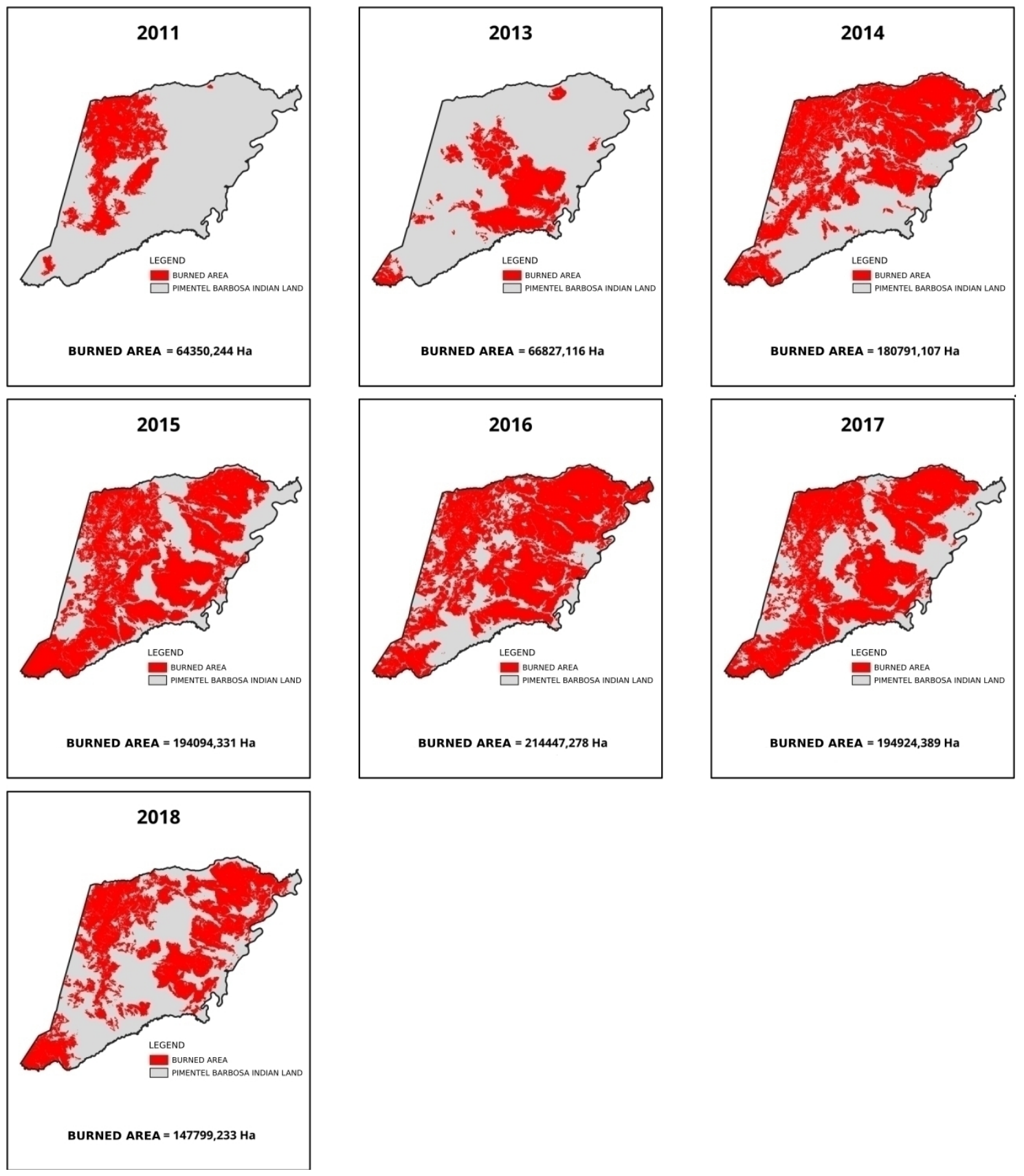

Figure 6 - Annual distribution of fire events (2008 - 2018). 


\section{FIRE FREQUENCY}

The frequency of the fires was distributed between zero and 34 repetitions (Figures 7 and 8). The areas with the highest rates of burning had an incidence of 20 events within the 34-year study period, totaling an area of approximately $18,660,559$ ha. Only $21,757,807$ ha (6.61\%) of the PBIL's area had no fires, and 10,470,690 ha (3.18\%) had only one fire during the period evaluated.

The locations with no or low frequency of fires were areas with natural barriers, that is, natural firebreaks that prevent fires from spreading, such as rivers, gallery forests, humid valleys, and scarp areas of the Serra do Roncador Mountain Range (FRANÇA; RIBEIRO, 2008, MESQUITA et al., 2010).

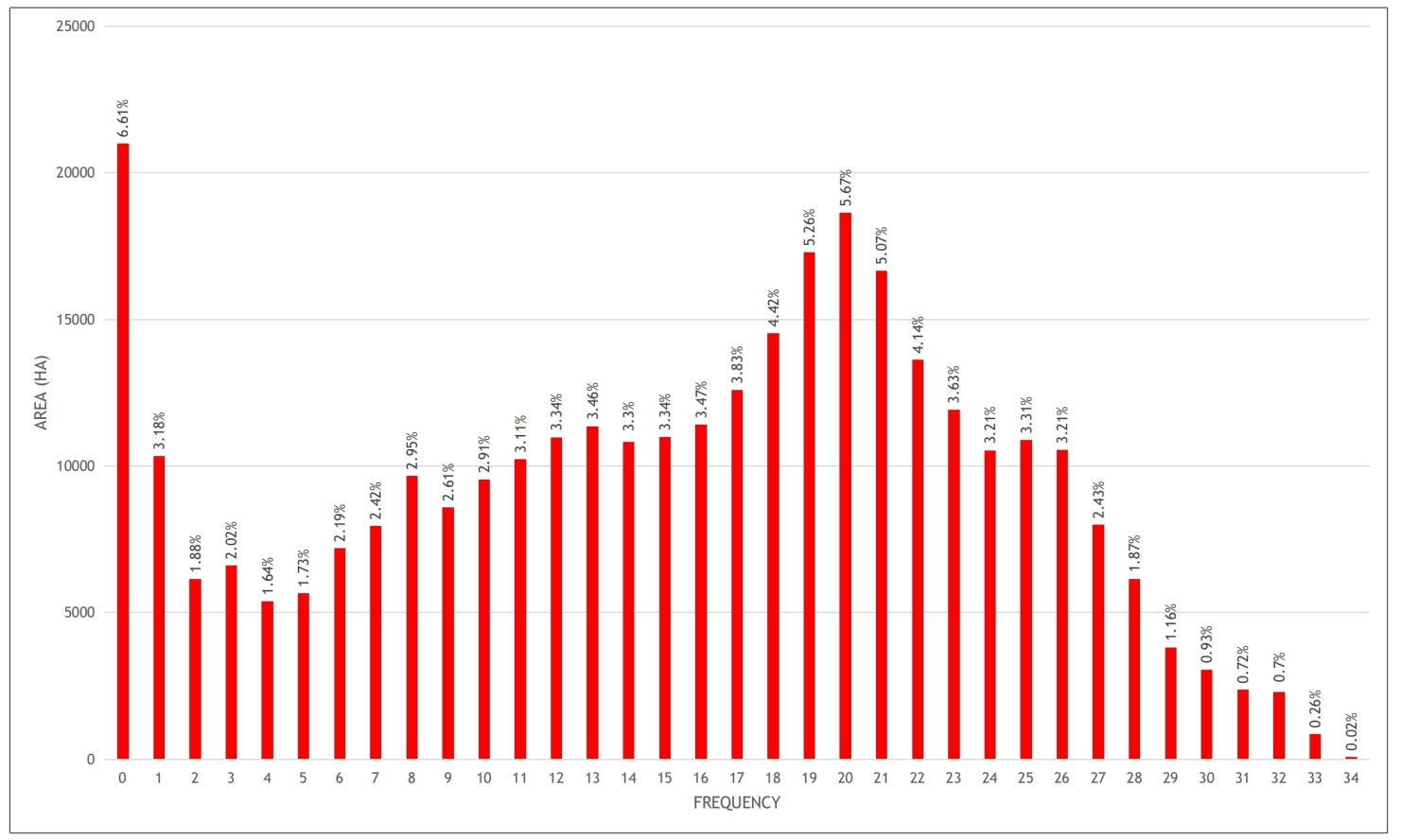

Figure 7 - Areas of the PBIL by frequency of fire from 1984 to 2018 (except 2012).

The high density (number of fires within an area), size, frequency, and recurrence of fires in the PBIL can be attributed to changes in the Xavante's hunting practices and the decrease and fragmentation of their territory over the last century (STEARMAN, 1999).

Originally the Xavante were hunter-gatherers and itinerant farmers whose semi-nomadic lifestyle was characterized by their mobility and the long periods when they were dispersed in the territory. This movement through the territory was how they used space (territoriality), staying in their villages for few months of the year during harvest periods, and exploring the territory in large groups during hunting and gathering expeditions. The actual villages did not have a definitive location (SILVA, 1992). 


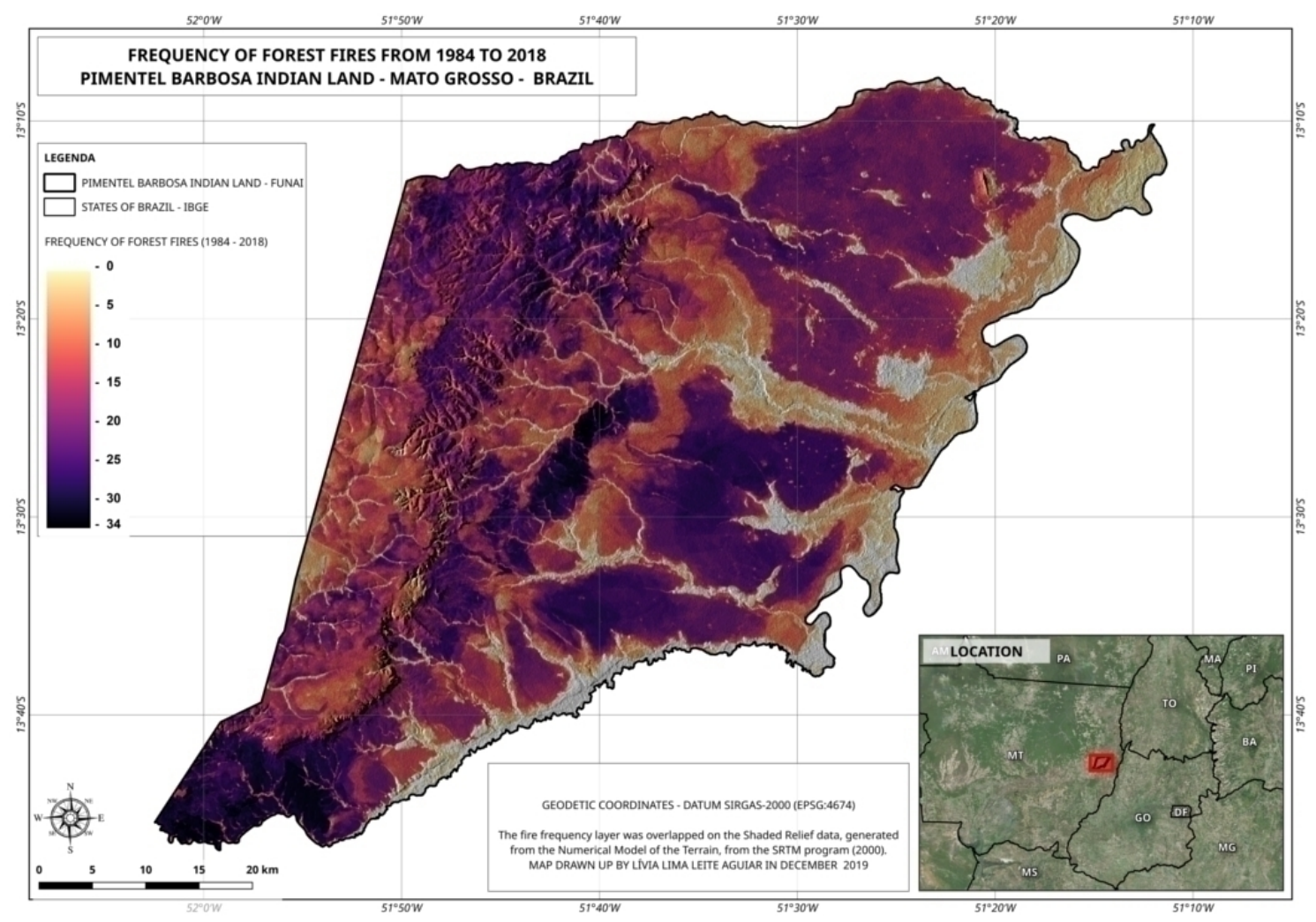

Figure 8 - Map of the frequency of fires in the Pimentel Barbosa Indigenous Land from 1984 to 2018 (except 2012).

The migrations that occurred in the eighteenth and nineteenth centuries explain the Xavante's exit from the state of Goiás to the state of Mato Grosso, due to military campaigns, invasions, and attacks on their villages (MAYBURY-LEWIS, 1984). It was only in 1940 that the Xavante yielded to contact with the non-Indigenous population, starting a process that transformed their culture.

The fragmentation of the Xavante territory began in 1942, with the occupation of the Central-West region of the country and crushing of the indigenous population (pacification) (AZANHA 2013). After several attempts of contact and acculturation between 1970 to 1980, FUNAI began to define legal lands for the Xavante. However, many disputes continue over the boundaries fixed in these processes, which did not correspond to those requested. Furthermore, some areas have still not been homologated (SOUZA et al., 2016).

According to Azanha (2013), the process of expropriation and fragmentation of the Xavante land is the result of an unfair dispute, driven by political issues and linked to the process of occupation by non-Indigenous settlers. These factors have changed the socio-environmental characteristics and cosmological views of Xavante culture, resulting in sociocultural distancing and the fragmentation of their culture as their lands were no longer contiguous. Also, communication between the different subgroups was lost. Thus, these people, who formerly occupied a large territory, ended up living in seven noncontiguous indigenous territories (SOUZA et al., 2016).

Some studies indicate that the frequency and intensity of fires set by the Xavante do not endanger animal populations (PRADA, 2001; PRADA; MARINHO-FILHO, 2004) and there are no significant differences between the number of animals found in burnt and unburnt areas (VILLALOBOS, 2002). Fragoso et al. (2000) reported that there is no indication of overhunting of the species pursued by the Xavante in the PBIL, however, some species are at risk of extinction due to the decrease in their habitats.

On the other hand, Leeuwenberg (1994) reported that the hunting of some species is not sustainable and recommended that the Xavante adopt managed hunting practices, which include the rotation of areas and optimal times for fires according to each plant typology, to reduce the pressure of hunting on threatened species. 


\section{FIRES ACCORDING TO PLANT TYPOLOGY AND SOIL USE}

Except for transition forests, all the plant typologies had more than $90 \%$ of their areas burned; in some cases, the fires affected the whole area covered by a plant typology (Table 1).

\begin{tabular}{|l|c|c|c|c|}
\hline Plant typologies and land use & $\begin{array}{c}\text { Total area } \\
\text { in the PBIL } \\
(\mathbf{H a})\end{array}$ & $\begin{array}{c}\text { Total area } \\
\text { in the PBIL } \\
(\boldsymbol{\%})\end{array}$ & $\begin{array}{c}\text { Burned area } \\
(\mathbf{H a})\end{array}$ & $\begin{array}{c}\text { Burned area } \\
(\boldsymbol{\%})\end{array}$ \\
\hline Agriculture & $7,098.71$ & 2.15 & $7,033.119$ & 99.08 \\
\hline Transition forest & $64,711.42$ & 15.08 & $49,388.991$ & 76.32 \\
\hline Arboreous savanna with riparian forest & $57,701.34$ & 16.74 & $54,823.924$ & 95.01 \\
\hline $\begin{array}{l}\text { Arboreous savanna without riparian } \\
\text { forest }\end{array}$ & $20,916.56$ & 6.31 & $20,682.657$ & 98.88 \\
\hline Dense savanna & $59,266.90$ & 16.54 & $54,193.710$ & 91.41 \\
\hline Park savanna with riparian forest & $117,896.47$ & 35.71 & $116,975.205$ & 99.22 \\
\hline
\end{tabular}

Table 1 - Total area and burned area according to each plant typology and land use.

Park savanna with riparian forest has the highest total and also occupies the largest area in the PBIL, with $116,975.205$ ha burned, representing approximately $35.70 \%$ of the PBIL and $99.22 \%$ of that typology (Table 1). The agricultural areas in the PBIL (2.15\%) had $99.08 \%$ of their area burned; in this case, the fire is more closely related to land management for pastures or crops than to hunting activities.

According to the frequency classes, there was a high frequency of fires in all the plant typologies, except for the transition forest. Park savanna with riparian forest presented the highest frequency $(93,346.16 \mathrm{ha}), 99.22 \%$ of this plant typology had a high frequency of fires (Figure 9).

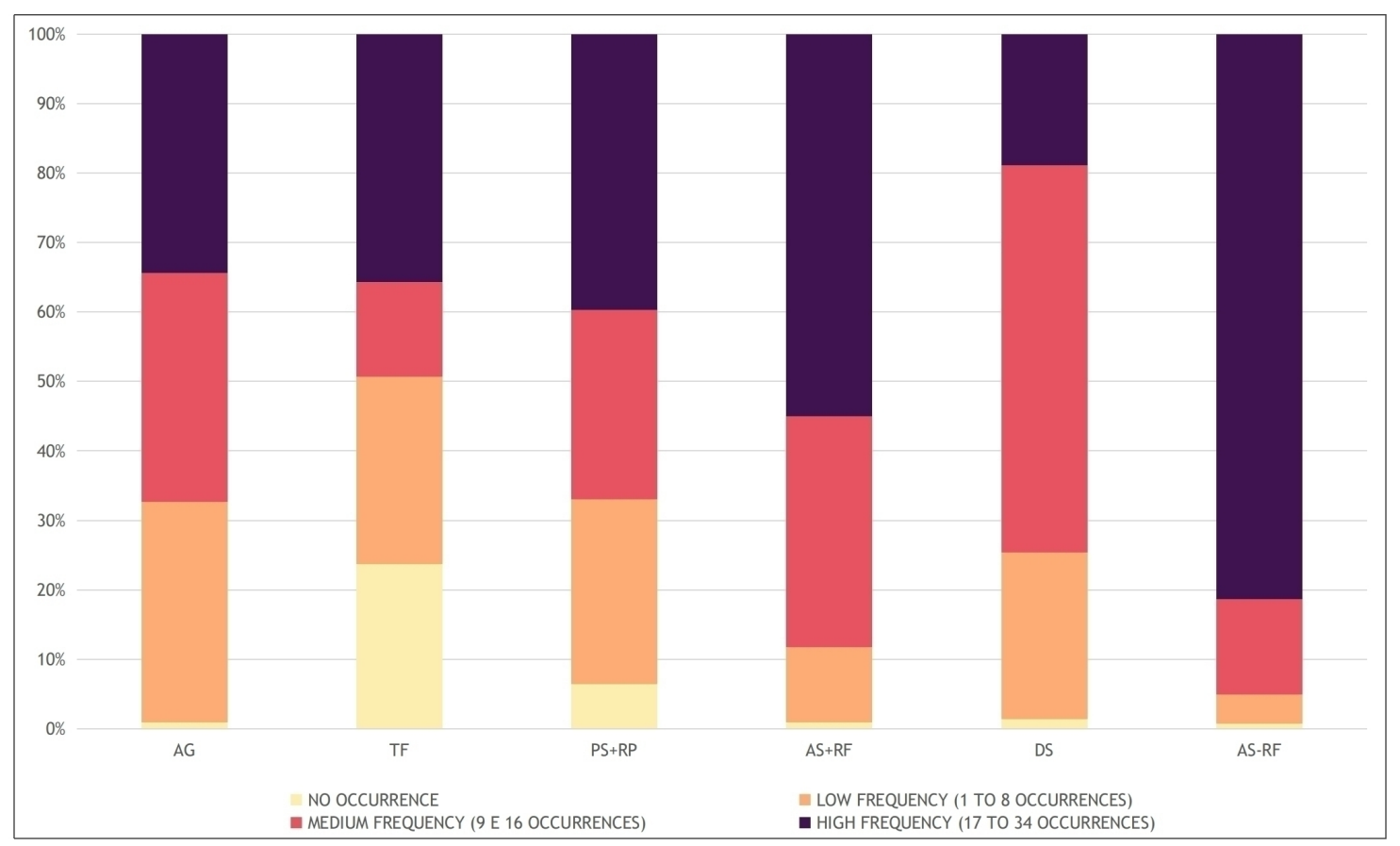

Figure 9 - Classes of fire frequency according to the plant typology. AG = agriculture; $\mathrm{TF}=$ transition forest; $\mathrm{PS}+\mathrm{RP}=$ park savanna with riparian forest; $\mathrm{AS}+\mathrm{RF}$ = arboreous savanna with riparian forest; DS $=$ dense savanna; AS-RF $=$ arboreous savanna without riparian forest.

The total exclusion of fires is not an option and may pose a potential threat to the savanna biome, which depends on fire events to maintain its structure, microclimate, diversity, and function. Moreover, indiscriminate fire damage can alter plants, thus reducing the Cerrado' biodiversity, and affecting climatic, economic, and cultural processes (MEDEIROS; FIELDLER, 2011; DURIGAN; RATTER, 
2015). Hence the need to better understand the correlation between fire and vegetation to ensure the best possible management.

The amount and consumption of fine combustible biomass by fire differ depending on the plant physiology. Park savanna (grasslands or sparse Cerrado) occupies an extensive area with a high frequency of fires due to the vegetation's architecture and phenology since most of the fine biomass is composed of grass species, which are very prone to fire in the dry season (MIRANDA et al., 1996; CONCEITION; PIVELLO, 2011; FRANÇA et al., 2007). This high flammability is maintained by a positive feedback mechanism: fires reduce the arboreous vegetation, favoring the expansion of grass species, and, consequently, increase the ecosystem's combustibility, thus promoting the occurrence of new fires (BEERLING; OSBORNE, 2006; HOFFMANN et al., 2012).

In the Cerrado's denser vegetation, also known as Cerradão or dense savanna, the fine biomass derives from the dead material in contact with the soil surface (litterfall). The fire dynamics in this environment are affected by the microclimate, as tree and shrub shadows cause higher moisture rates in the flammable substance, which also affects the temperature and burning time, resulting in patches with and without fires (KAUFFMAN et al., 1994). Nevertheless, fire can reduce the plant biomass and litterfall, altering the flow of energy, nutrients, and water (FROST; ROBERTSON, 1987; MEDINA; SILVA, 1990).

The interval between fires, which enables the Cerrado vegetation to survive without large ecological losses, also varies according to the vegetation. Studies have indicated fire intervals of two and three years, respectively, for park savanna (NASCIMENTO NETO et al., 1998) and typical Cerrado vegetation (PIVELLO; COUTINHO, 1992; KAUFFMAN et al., 1994).

Frequent burnings impede the vegetation's regeneration, reducing the time for plants to establish and regrow (SILVA et al., 1996). Damage to the shrub-arboreous extract increases as the fire frequency rises, resulting in significant changes to the vegetation's structure and composition. It may be advisable to use fire regimes with intervals over four years (SATO et al., 2010).

The physiological, morphological, and ecological differences between savanna and forest species explain the variations in their tolerance to fire (BOND; WILGEN, 1996), which favor savanna species. The thicker bark of savanna species, when compared to forest species, provides a higher capacity to withstand conflagrations. On average, the roots of savanna species are, in $82 \%$ bigger than those of forest species (HOFFMANN; FRANCO, 2003), which also contributes to their capacity to survive and grow back (HOFFMANN; MOREIRA, 2002).

The high frequency of burning causes several types of damage to arboreous vegetation in the Cerrado. It changes the vegetation structure, decreases the arboreous density, and prevents the recovery of plants to heights sufficient to avoid the direct effect of flames (SATO, 2003). There is a fall in the recruitment of woody varieties and the richness and diversity of species (HOFFMANN et al., 2012; MEDEIROS; MIRANDA, 2005), whilst invasion by exotic grass species increases (SILVÉRIO et al., 2013). The impact of fire on the vegetation does not only depend on aspects related to the interval of regeneration. It also varies according to other characteristics of the burning, such as the intensity, severity, and propagation speed (LUKE; MCARTHUR, 1978; SATO; MIRANDA, 1996).

Fire management using prescribed periodical fires is a possible alternative when planning hunting activities, resulting in less intense, more fragmented, and thus less destructive fires (RAMOS-NETO; PIVELLO, 2000; COUTINHO, 1990). Also, this management breaks up the amount of burned biomass, forming a patchwork of burned and unburned landscapes, which decreases the occurrence and extension of fires at the end of the dry season, and maximizes habitat diversity (BEATTY, 2013).

Fire management can be understood as a set of practices and technical decisions to prevent, control, and manipulate fires in a landscape to meet specific objectives (MYERS; BATALHA, 2006). Prescribed fires in the USA, Canada, and Australia have been used for decades to reduce the burned biomass and avoid the catastrophic fires that affect these regions (SEILER; CRUTZEN, 1980).

Governmental fire management actions in Indigenous lands in Brazil are carried out by the Brazilian Institute of Environment and Renewable Natural Resources (IBAMA), through the actions of the Brazilian Center for Prevention and Combat of Forest Fires (PREVFOGO), which is responsible for policies to prevent and fight forest fires in the whole country. Since 2007, PREVFOGO has worked in partnership with FUNAI on a fire management program in the Indigenous lands of different ethnic 
groups (Irantxe, Myky, Paresi, and Nambikwara) who live in the western state of Mato Grosso. These Lands had been exposed to fires with no control of their intensity, frequency, period, and the size of the areas, causing environmental degradation and economic losses (FALLEIRO, 2011). This program's actions consider that recovering the traditional fire management of Indigenous communities in the Cerrado is essential to the process and part of the strategies to prevent and control forest fires (VELEZ, 2005; IBAMA, 2009).

\section{CONCLUSION}

A series of changes have occurred in the Xavante's culture following their contact with non-Indigenous populations. Formerly, they were semi-nomads moving through a continuous territory, but the fragmentation and spatial limitation of their territory and the integration of their culture to Brazilian social norms changed this itinerant way of life. Collective hunting using fire for social and food purposes, which was practiced in a sparse and environmentally orientated form, was converted into a hunting practice characterized by an increasing amount of fire events in the same area leading to a non-sustainable model for the local fauna and flora.

The Pimentel Barbosa Indigenous Land (PBIL) has an uncontrolled fire regime in terms of the frequency or extension of the fires, which affects all the types of vegetation in the area. It is evident that the physical and biological resources of the PBIL should be preserved to encourage the sustainable recovery of historical-cultural aspects so that they can be celebrated and continued.

In this context, there is a need to implement practices that mitigate the impacts of uncontrolled fires for hunting and manage natural resources. These actions include reinstating traditional Xavante fire management, allowing a four-year minimum fallow period without fires in forest areas, and at least two fire-free years in the savanna. Fire control techniques and traditional management should be adopted together with governmental conservation programs to control flammable plant biomass. Systematic monitoring of fire events should be carried out to prevent and combat fires, as well as new surveys of the fauna in the PBIL.

\section{ACKNOWLEDGEMENTS}

Lívia Lima Leite Aguiar is grateful to the Universidade Estadual de Goiás (UEG) for the Master's scholarship (PPGSS em Recursos Naturais do Cerrado). This study was financed in part by the Coordenação de Aperfeiçoamento de Pessoal de Nível Superior - Brasil (CAPES) - Finance Code 001 (Convênio $n^{\circ}$ 817164/2015 CAPES/PROAP).

\section{REFERENCIAS}

ALVARADO, S. T.; SILVA, T. S. F.; ARCHIBALD, S. Management impacts on fire occurrence: A comparison of fire regimes of African and South American tropical savannas in different protected areas. Journal of Environmental Management, v. 218, p. 79-87, 2018.

ARAÚJO, F. M.; FERREIRA, L. G.; ARANTES, A. E. Distribution Patterns of Burned Areas in the Brazilian Biomes: An Analysis Based on Satellite Data for the 2002-2010 Period. Remote Sensing, v. 4, 1929-1946, 2012.

AZANHA, G. Ferrovia EF-354: Estudos etnoecológicos dos Impactos nas terras indígenas Parabubu-Culuene, Areões, Pimentel Barbosa e Marechal Rondon. Brasília-DF: STE/VALEC, 2013.

FALLEIRO, R. M.; SANTANA, M. T.; BERNI, C. R. As contribuições do Manejo Integrado do Fogo para o controle dos incêndios florestais nas Terras Indígenas do Brasil. Biodiversidade Brasileira, v. 6, n. 2, p. 88-105, 2016.

BEERLING, D.J.; OSBORNE, C.P. The origin of the savanna biome. Glob. Chang. Biol., v. 12, n. 11, p. 2023-2031, 2006. 
BOND, W. J.; WILGEN, B. W.V. Fire and Plants. Chapman \& Hall, London, 1996. 263 p.

BOWMAN, D. M. J. S.; MURPHY, B. P. Fire and biodiversity. In: SODHI, N. S.; EHRLICH (Edits.) Conservation Biology for all. Oxford University Press, 2010. p. 163-180.

CHUVIECO, E. Global Impacts of Fire. In: CHUVIECO ,E. (ed.) Earth Observation of Wildland Fires in Mediterranean Ecosystems. Springer: Berlin, Heidelberg, 2009. p. 1-10.

CONCEIÇÃO, A. A.; PIVELLO, V. R. Biomassa combustível em campo sujo no entorno do Parque Nacional da Chapada Diamantina, Bahia, Brasil. Biodiversidade Brasileira, ano I, n. 2: p. 146-160, 2011.

COUTINHO, L. M. Fire in the ecology of the Brazilian cerrado. In: GOLDAMMER, J.G. (Ed.). Fire in the Tropical Biota: Ecosystem Processes and Global Challenges. New York: Columbia University Press, 1990. p. 82-105.

DAlDEGAN, G. A.; CARVALHO JÚNIOR, O. A.; GUIMARÃES, R. F.; GOMES, R. A. T.; RIBEIRO, F. F.; MCMANUS, C. Spatial Patterns of Fire Recurrence Using Remote Sensing and GIS in the Brazilian Savanna: Serra do Tombador Nature Reserve, Brazil. Remote Sensing 2014, v. 6, n. 10, p. 9873-9894, 2014.

DURIGAN, G., RATTER, J. A. The need for a consistent fire policy for Cerrado conservation. J. Appl. Ecol., v. 53, n. 1, p. 11-15, 2015.

EITEN, G. The cerrado vegetation of Brazil. The Botanical Review, v. 38, n. 2, p. 201-341, 1972.

FALLEIRO, R. M. Resgate do manejo tradicional do cerrado com fogo para proteção das terras indígenas do oeste do Mato Grosso: um estudo de caso. Biodiversidade brasileira, ano I, n. 2, p. 86-96, 2011.

FALLEIRO, R. M.; SANTANA, M. T.; BERNI, C. R. As contribuições do Manejo Integrado do Fogo para o controle dos incêndios florestais nas Terras Indígenas do Brasil. Biodiversidade Brasileira, v. 6, n. 2, p. 88-105, 2016.

FRAGOSO, J. M. V., SILVIUS K. M.; VILLALOBOS M. P. Manejo de Fauna na Reserva Xavante Rio das Mortes: Cultura Indigena e Método Cientifico Integrados Para Conservação. WWF Brasil, Brasília, 2000 , v. 4.68 p.

FRANÇA, H.; RAMOS NETO, M. B.; SETZER, A. O Fogo no Parque Nacional das Emas. Ministério do Meio Ambiente. Série Biodiversidade, 27, 2007. 140 p.

FRANÇA, H.; RIBEIRO, K. T. Mapeamento de queimadas no Parque Nacional da Serra do Cipó e na Área de Proteção Ambiental Morro da Pedreira, MG: 1984-2007. Relatório Técnico. 2008. 75p.

FRANÇA, H. Os incêndios de 2010 nos parques nacionais do cerrado. Relatório técnico. Universidade Federal do ABC. 16p., 2010.

FROST, P. H. G.; ROBERTSON, F. The ecological effects of fire in savannas. In: WALKER, B. H. (Edit.) Determinants of Tropical Savannas. IRL Press: Oxford, 1987. p. 93-141.

FUNAI. Fundação Nacional do Índio. Indíos do Brasil. Disponível em: http://www.funai.gov.br/index.php/indios-no-brasil/terras-indigenas. Acesso em 22 mar. 2019.

GIGLIO, L.; CSISZAR, I.; JUSTICE, C. O. Global distribution and seasonality of active fires as observed with the Terra and Aqua Moderate Resolution Imaging Spectroradiometer (MODIS) sensors. J. Geom. Phys., v. 111, n. G2, 2006.

HOFFMANN, W. A.; FRANCO, A. C. Comparative growth analysis of tropical forest and savanna woody plants using phylogenetically independent contrasts. Journal of Ecology, v. 91, n. 3, p. 475-484, 2003.

HOFFMANN, W. A.; MOREIRA, A. G. The role of fire in population dynamics of woody plants. In: OLIVEIRA, P. S.; MARQUIS, R. J. The Cerrados of Brazil: ecology and natural History of a 
neotropical savanna, Columbia University Press, 2002. p. 159-177, 2002.

HOFFMANN, W. A.; GEIGER, E. L.; GOTSCH, S. G.; ROSSATTO, D. R.; SILVA, L. C. R.; LAU, O. L.; HARIDASAN, M.; FRANCO, A. C. Ecological thresholds at the savanna-forest boundary: how plant traits, resources and fire govern the distribution of tropical biomes. Ecology Letters, v. 15, n. 7, p. 759-768, 2012.

IBAMA. Instituto Brasileiro do Meio Ambiente e dos Recursos Naturais Renováveis. MMA. Ministério do Meio Ambiente. Roteiro Metodológico para Elaboração de Planos Operativos de Prevenção e Combate aos Incêndios Florestais. CNIA/Brasília, 2009. 32 p.

IBGE. Instituto Brasileiro de Geografia e Estatistica. Censo demográfico, v. 2010, 2010. Disponivel em: https://www.ibge.gov.br/busca.html?searchword=indios. Acesso em: 18 dez. 2019.

IBGE. Instituto Brasileiro de Geografia e Estatistica. Manual técnico da vegetação brasileira. Manuais técnicos em Geociências, 2012.

ISA. Instituto Socioambiental. Terras indígenas no Brasil. Disponível em: https://terrasindigenas.org.br/es/terras-indigenas/3821. Acesso em 11 jun. 2019.

KARKANAS, P.; SHAHACK-GROSS, R.; AYALON, A.; BAR-MATTHEWS, M.; BARKAI, R.; FRUMKIN, A.; GOPHER, A.; STINER, M. C. Evidence for habitual use of fire at the end of the Lower Paleolithic: Site-formation processes at Qesem Cave, Israel. Journal of Human Evolution, n. 53, v. 2, p. 197-212, 2007.

KAUFFMAN, J. B., CUMMINGS, D. L., WARD, D. E. Relationships of fire, biomass and nutrient dynamics along a vegetation gradient in the Brazilian Cerrado. J. Ecol., v. 82, n. 3, p. 519-531, 1994.

LEEUWENBERG, F. Análise Etno-zoológica e manejo da fauna cinegética na Reserva Indígena Xavante Rio das Mortes, aldeia Etenhiritipá, Mato Grosso, Brasil. Relatório final para o Centro de Pesquisa Indígena. Wildlife Conservation International/WCI, Fundo Mundial para a natureza-WWF e Fundação Gaia-UK, 1994.

LEEUWENBERG, F. Manejo de fauna cinegética na Reserva Indígena Xavante de Pimentel Barbosa, estado do Mato Grosso. Manejo de conservação de vida silvestre no Brasil. MCT/CNPq e Sociedade Civil Mamirauá, p. 233-238, 1997.

LEEUWENBERG, F. J.; ROBINSON, J. G. Traditional Management of Hunting by a Xavante Community in Central Brazil: The Searehfor Sustainability. In: ROBINSON, J. G.; BENNETT, E. (Edits.) Hunting for Sustainability in Tropical Forests. Columbia University Press, 2000. p. 375-394.

LEWIS, H. T.; FERGUSON, T. A. Yards, corridors, and mosaics: how to burn a boreal forest. Human Ecology, v. 16, n.1, p. 57-77, 1988.

LUKE, R. H.; MCARTHUR, A. G. Bush fires in Australia. Bush Fires in Australia, 1978. 359 p.

MAYBURY-LEWIS, D.; DA SILVA, A. L. A sociedade Xavante. Editora Francisco Alves, 1984.

MEDEIROS, M. B. de; FIEDLER, N. C. Heterogeneidade de ecossistemas, modelos de desequilíbrio e distúrbios. Biodiversidade Brasileira, ano I, n. 2, p. 4-11, 2011

MEDEIROS, M. B.; MIRANDA, H. S. Mortalidade pós-fogo em espécies lenhosas de campo sujo submetido a três queimadas prescritas anuais. Acta bot. bras., v. 19, n. 3, p. 493-500, 2005.

MEDINA, E.; SILVA, J. F. Savannas of northern South America: a steady state regulated by water-fire interactions on a background of low nutrient availability. Journal of Biogeography, v. 17, n. 4, p. 403-413, 1990.

MELO, M. M.; SAITO, C. H. Regime de queima das caçadas com uso do fogo realizadas pelos Xavante no cerrado. Biodiversidade Brasileira, Ano I, n. 2, p. 97-109, 2011.

MELO, M. M. The practice of burning savannas for hunting by the Xavante Indians based on the stars and constellations. Soc. Natur. Resour., v.26, n. 4, p. 478-487, 2013. 
MESQUITA, F. W.; LIMA, N. R. G.; GONÇALVES, C. N.; BERLINCK, C. N.; LINTOMEN, B. S. Histórico dos incêndios na vegetação do Parque Nacional da Chapada Diamantina, entre 1973 e abril de 2010, com base em imagens Landsat. Biodiversidade Brasileira, ano I, n. 2, p. 228-246, 2011.

MIRANDA, H. S.; SILVA, E. P. R.; MIRANDA, A. C. Comportamento do fogo em queimadas de campo sujo. In: Impactos de queimadas em áreas de cerrado e restinga: Anais do Simpósio Impacto das Queimadas sobre os Ecossistemas e Mudanças Globais, $3^{\circ}$ Congresso de Ecologia do Brasil, 6 a 11 de outubro de 1996, Brasília-DF. p. 1-10, 1996.

MIRANDA, H. S. et al. The fire factor. The Cerrados of Brazil: ecology and natural history of a neotropical savanna, p. 51-68, 2002.

MIRADA, H. S.; NASCIMENTO NETO, W.; NEVES, B. M. C. Caracterização das queimadas de Cerrado. In: H.S. Miranda (ed.) Efeitos do regime do fogo sobre a estrutura de comunidades de Cerrado: resultados do Projeto Fogo. IBAMA, p. 23-34, 2010.

MISTRY, J.; BIZERRIL, M. Por que é importante entender as inter-relações entre pessoas, fogo e áreas protegidas? Biodiversidade Brasileira. ano I, n. 2, p. 40-49, 2011.

MYERS, R. L.; BATALHA, M. Convivendo com o Fogo-Manutenção dos ecossistemas e subsistência com o manejo integrado do fogo. The Nature Conservancy - Iniciativa Global para o Manejo do Fogo: Tallahassee, USA, 2006.

NARDOTO, G. B. et al. Nutrient use efficiency at ecosystem and species level in savanna areas of Central Brazil

and impacts of fire. Journal of Tropical Ecology, v. 22, p.191-201, 2006.

NASCIMENTO NETO, W.; ANDRADE S. M. A; MIRANDA H. S .The dynamics of the herbaceous layer following prescribed burning: a four year study in the Brazilian savanna. In: 14th Conference on Fire and Forest Meteorology 2, DX, 1998, Coimbra, Portugal. Proceedings... p. 1785-1792.

NOVAIS, G. T. Classificação climática aplicada ao Bioma Cerrado. 2019. 184 f. Tese (Doutorado em Geografia) - Universidade Federal de Uberlândia, Uberlândia, MG, 2019.

PAULINO, B. G.; MARTINS, P. T. A. Análise temporal da ocorrência de incêndios florestais no Parque Estadual da Serra de Caldas Novas (PESCaN), Goiás. Revista Brasileira de Geografia Física, v. 9, p. 1465-1485, 2016.

PAUSAS, J. G.; KEELEY, J. E. A burning story: the role of fire in the history of life. BioScience, v. 59, n. 7, p. 593-601, 2009.

PEREIRA, J. M. C. Remote sensing of burned areas in tropical savannas. International Journal of Wildland Fire. n. 12, p. 259-270, 2003.

PEREIRA JÚNIOR, A. C.; GAMA, V. F. Anthropization on the Cerrado biome in the Brazilian Uruçuí-UnaEcological Station estimated from orbital images. Brazilian Journal of Biology, v. 70, n. 4, p. 969-976, 2010.

PIRES, E. G.; FERREIRA JÚNIOR, L. G. Mapeamento da temperatura de superfície a partir de imagens termais dos satélites Landsat 7 e Landsat 8. In: Simpósio Brasileiro de Sensoriamento Remoto-SBSR, XVII, 2015, João Pessoa-PB. Anais [...] 2015. p. 7421-7428.

PIVELLO, V. R. The use of fire in the cerrado and amazonian rainforests of Brazil: past and present. Fire Ecology, v. 7, n. 1, 2011.

PIVELLO, V. R.; COUTINHO, L. M. Transfer of macronutrients to the atmosphere during experimental burnings in an open cerrado (brazilian savanna). Journal of Tropical Ecology, v. 8, n. 4, p. 487-497, 1992.

POSEY, D. A. Ethnoentomological survey of Brazilian indians. Entomologia Generalis, v 12, n. 2-3, p. 191-202, 1987. 
PRADA, M. Effects of fire on the abundance of large mammalian herbivores in Mato Grosso, Brazil. Mammalia, v. 65, n. 1, p. 55-62, 2001.

PRADA, M.; MARINHO-FILHO, J. Effects of fire on the abundance of Xenarthrans in Mato Grosso, Brazil. Austral Ecology, v. 29, n. 5, p. 568-573, 2004.

RAMOS NETO M. B.; PIVELLO V. R. Lightning fires in a Brazilian savana national park: Rethinking management strategies. Environ. Manage, v. 26, n. 6 p. 675-684, 2000.

SANO, E. E. FERREIRA, L. G.; ASNER, G. P.; STEINKE, E. T. Spatial and temporal probabilities of obtaining cloud-free Landsat images over the Brazilian tropical savanna. International Journal of Remote Sensing, v. 28, n 12, p. 2739-2752, 2007.

SATO, M. N. Efeito a longo prazo de queimadas prescritas na estrutura de comunidade de lenhosas da vegetação do cerrado sensu stricto. 2003. 84f. Tese (Doutorado em Ecologia) - Universidade de Brasília, Brasília, DF, 2003.

SATO, M. N.; GARDA, A. A.; MIRANDA, H. S. Effects of fire on the mortality of woody vegetation in Central Brazil. In: 14th Conference of Fire and Forest Meteorology II. Proceedings. p. 1785-1792, 1998.

SATO, M. N.; MIRANDA, H. S. Mortalidade de plantas lenhosas do cerrado sensu stricto submetidas a diferentes regimes de queima. In: Impactos de queimadas em áreas de cerrado e restinga: anais do Simpósio Impacto das Queimadas sobre os Ecossistemas e Mudanças Globais, $3^{\circ}$ Congresso de Ecologia do Brasil, 6 a 11 de outubro de 1996, Brasília-DF. p. 1-10, 1996.

SATO, M. N.; MIRANDA, H. S.; MAIA, J. M. F. O fogo e o estrato arbóreo do Cerrado: efeitos imediatos e longo prazo. In: H. S. MIRANDA (ed.). Efeitos do regime do fogo sobre a estrutura de comunidades de cerrado: resultados do Projeto Fogo. IBAMA/MMA, 2010. p. 77-91.

SCHMIDT, I. B.; FONSECA, C. B, FERREIRA, M. C.; SATO, M. N. Implementação do programa piloto de manejo integrado do fogo em três unidades de conservação do Cerrado. Biodiversidade Brasileira, v. 6, n. 2, p. 55-70, 2016.

SCHMIDT, I. B.; MOURA, L. C.; FERREIRA, M. C.; ELOY, L.; SAMPAIO, A. B.; DIAS, P. A.; BERLINCK, C. N. Fire management in the Brazilian savanna: first steps and the way forward. Journal of applied ecology, v. 55, n. 5, p 2094- 2101, 2018. https://doi.org/10.1111/1365-2664.13118

SEILER, W.; CRUTZEN, P. J. Estimates of gross and net fluxes of carbon between the biosphere and the atmosphere from biomass burning. Climatic change, v. 2, n. 3, p. 207-247, 1980.

SILVA, A. L. Dois séculos e meio de história Xavante. In: CUNHA, M. C. (Org.) História dos índios no Brasil. São Paulo: Companhia das Letras, Fundação Amparo a Pesquisa no Estado de São Paulo, Secretaria Municipal de Cultura, 1992. p. 357-378.

SILVA, G. T.; SATO, M. N.; MIRANDA, H. S. Mortalidade de plantas lenhosas em um campo sujo de cerrado submetido a queimas prescritas. In: Impactos de queimadas em áreas de cerrado e restinga: anais do Simpósio Impacto das Queimadas sobre os Ecossistemas e Mudanças Globais, $3^{\circ}$ Congresso de Ecologia do Brasil, 6 a 11 de outubro de 1996, Brasília-DF. p. 1-10, 1996.

SILVÉRIO, D. V.; BRANDO P. M.; BALCH J. K.; PUTZ F. E.; NEPSTAD D. C.; OLIVEIRA-SANTOS C.; BUSTAMANTE M. M. Testing the Amazon savannization hypothesis: fire effects on invasion of a neotropical forest by native cerrado and exotic pasture grasses. Philos. Trans. R. Soc. B., v. 368, 2013.

SOUZA, L. G.; GUGELMIN, S. A.; CUNHA, B. C. B.; ATANAKA, M. Os indígenas Xavante no Censo Demográfico de 2010. Revista Brasileira de Estudos de População, v. 33, n. 2, p. 327-347, 2016.

STEARMAN, A. M. Cambio social, cacería y conservación en pueblos indígenas. Puntos de conflicto y caminos hacia la resolución. In: FANG, T. G.; MONTENEGRO, O. L.; BODMER, R. E. (Ed.). Manejo y conservación de fauna silvestre en America Latina. La Paz: Instituto de Ecología, 1999. 
VELEZ, R. Community based fire management in Spain. Forest Protection Working Papers (FAO), 2005.

VILLALOBOS, M. P. V. Efeito do fogo e da caça na abundância de mamíferos na Reserva Xavante do Rio das Mortes, MT, Brasil. 2002. 80 f. Tese (Doutorado em Biologia Animal)-Universidade de Brasília, Brasília, 2002.

WELCH, J. R.; SANTOS, R. V.; FLOWERS, N. M.; COIMBRA JÚNIOR, C. E. A. Na Primeira Margem do Rio: Território e Ecologia do Povo Xavante de Wedezé. Rio de Janeiro: Museu do Índio/FUNAI, 2013. 248p.

WILlIAMS, D. L.; GOWARD, S.; ARVIDSON, T. Landsat: Yesterday, Today, and Tomorrow. Photogrammetric Engineering \& Remote Sensing, v. 72, n. 10, p. 1171-1178, 2006. 